\title{
Salmonellosis in calves without intestinal lesions ${ }^{1}$
}

\author{
Carolina C. Guizelini² (D), Rayane C. Pupin² ${ }^{2}$ Cássia R.B. Leal ${ }^{3}$, \\ Carlos A.N. Ramos ${ }^{4}$, Saulo P. Pavarini ${ }^{5}$ (D), Danilo C. Gomes ${ }^{2}$ (D), Tessie B. Martins ${ }^{2}$ \\ and Ricardo A.A. Lemos ${ }^{2 *}$ (D)
}

\begin{abstract}
Guizelini C.C., Pupin R.C., Leal C.R.B., Ramos C.A.N., Pavarini S.P., Gomes D.C., Martins T.B. \& Lemos R.A.A. 2019. Salmonellosis in calves without intestinal lesions. Pesquisa Veterinária Brasileira 39(8):580-586. Laboratório de Anatomia Patológica, Faculdade de Medicina Veterinária e Zootecnia, Universidade Federal de Mato Grosso do Sul, Av. Senador Filinto Muller 2443, Bairro Vila Ipiranga, Campo Grande, MS 79074-460, Brazil. E-mail: ricardo.lemos@ufms.br

Salmonellosis is a known cause of enteric disorders in calves. However, cases in the septicemic form may not present enteric lesions, which may lead the veterinary practitioner to not suspect salmonellosis, compromising the diagnosis. The current study describes the epidemiological, clinical, pathological and immunohistochemical aspects of septicemic salmonellosis in calves without enteric lesions. The protocols involving bovine material submitted to the Pathology Laboratory (LAP) of the "Faculdade de Medicina Veterinária e Zootecnia" (FAMEZ) of the "Universidade Federal do Mato Grosso do Sul" (UFMS) from January 1995 to July 2018 were studied. Cases confirmed or suggestive of septicemic salmonellosis in calves without enteric manifestations were selected. Fragments of the liver, lung, and spleen embedded in paraffin were submitted to immunohistochemistry (IHC). Only cases in which there was positive marking on the IHC or culture isolation of Salmonella were included in this study. Of a total of 5,550 cattle examined in the period, ten presented septicemic salmonellosis without enteric lesions. Clinical signs included mucosal pallor, apathy, hyperthermia, and dyspnea. Only three calves presented diarrhea, and two were found dead before clinical changes were observed. The most common necropsy findings were hepatosplenomegaly; yellow, orange or brown discolored livers; pale mucous membranes; inflated and sometimes red lungs; fibrin or fluid within body cavities; and gallbladder filled with inspissated bile. Jaundice was observed in three calves that had a concomitant infection with Anaplasma sp. Microscopically, paratyphoid hepatic nodules and interstitial pneumonia were the most frequent manifestations, followed by thrombosis and bacterial colonies in the spleen, lung, liver, and brain. A strong positive marking was observed in IHC, predominantly in the lung and to a lesser extent in the liver. Polymerase chain reaction (PCR) indicated the Dublin serotype as the causative agent in the samples of the four calves submitted to this procedure. In calves, the septicemic form was the major cause of death due to salmonellosis. Septicemic salmonellosis was usually not accompanied by diarrhea. The clinical signs of septicemia are nonspecific and of little assistance in the diagnosis. IHC has been shown to be efficient in the detection of the agent, mainly in the lung and especially in situations where it is not possible to perform bacterial culture.
\end{abstract}

INDEX TERMS: Salmonellosis, calves, diseases of cattle, Salmonella Dublin, septicemia, immunohistochemistry, cattle, bacterioses.

\footnotetext{
${ }^{1}$ Received on March 11, 2019.

Accepted for publication on March 20, 2019.

This work is part of the requirements for obtaining the Master's Degree by the first author.

${ }^{2}$ Laboratório de Anatomia Patológica, Faculdade de Medicina Veterinária e Zootecnia (FAMEZ), Universidade Federal de Mato Grosso do Sul (UFMS), Av. Senador Felinto Muller 2443, Bairro Vila Ipiranga, Campo Grande, MS 79074-460, Brazil. *Corresponding author: ricardo.lemos@ufms.br
}

\footnotetext{
${ }^{3}$ Laboratório de Bacteriologia, Faculdade de Medicina Veterinária e Zootecnia (FAMEZ), Universidade Federal de Mato Grosso do Sul (UFMS), Av. Senador Felinto Muller 2443, Bairro Vila Ipiranga, Campo Grande, MS 79074-460.

${ }^{4}$ Laboratório de Biologia Molecular, Faculdade de Medicina Veterinária e Zootecnia (FAMEZ), Universidade Federal de Mato Grosso do Sul (UFMS), Av. Senador Felinto Muller 2443, Bairro Vila Ipiranga, Campo Grande, MS 79074-460.

${ }^{5}$ Setor de Patologia Veterinária, Faculdade de Veterinária, Universidade Federal do Rio Grande do Sul (UFRGS), Av. Bento Gonçalves 9090, Porto Alegre, RS 91540-000, Brazil.
} 
RESUMO.- [Salmonelose em bezerros sem manifestações intestinais.] A salmonelose é uma causa conhecida de distúrbios entéricos em bezerros. Porém, casos na forma septicêmica podem não apresentar manifestação entérica, o que leva o médico veterinário a não suspeitar de salmonelose, comprometendo o diagnóstico. Este estudo descreve os aspectos epidemiológicos, clínicos, patológicos e imuno-histoquímicos da salmonelose septicêmica em bezerros sem lesões entéricas. 0 estudo foi realizado a partir dos protocolos referentes a materiais de bovinos enviados para diagnóstico ao Laboratório de Anatomia Patológica (LAP) da Faculdade de Medicina Veterinária e Zootecnia (FAMEZ) da Universidade Federal de Mato Grosso do Sul (UFMS) de janeiro de 1995 a julho de 2018. Foram selecionados os casos de bezerros confirmados ou sugestivos de salmonelose septicêmica sem lesões entéricas. Fragmentos de fígado, pulmão e baço embebidos em parafina foram submetidos ao exame de imuno-histoquímica (IHQ). Somente foram incluídos neste estudo casos em que houve marcação positiva na IHQ ou isolamento da bactéria em cultura. De um total de 5.550 bovinos examinados no período, dez apresentaram salmonelose septicêmica sem lesão entérica. Os sinais clínicos incluíram palidez de mucosas, apatia, hipertermia e dispneia. Apenas três bezerros apresentaram diarreia e dois foram encontrados mortos sem terem sido observadas alterações clínicas. Os achados mais frequentes de necropsia foram hepatoesplenomegalia, fígado amarelado, alaranjado ou acastanhado, palidez de mucosas, pulmões inflados e, por vezes, vermelhos, fibrina ou líquido nas cavidades do organismo e vesícula biliar repleta de bile grumosa. Icterícia foi observada em três bezerros que apresentavam infecção concomitante por Anaplasma sp. Microscopicamente, os nódulos paratifoides hepáticos e pneumonia intersticial foram as manifestações mais encontradas, seguidas por trombose e colônias bacterianas no baço, pulmão, fígado e encéfalo. Na IHQ, marcação fortemente positiva foi observada, predominantemente, no pulmão e, em menor intensidade, no fígado. A técnica de reação em cadeia de polimerase (PCR) tipificou o sorotipo Dublin como agente etiológico nas amostras dos quatro bezerros submetidos a este procedimento. Em bezerros, a forma septicêmica foi a principal responsável pelas mortes por salmonelose. Na maioria das vezes essa forma não estava acompanhada por diarreia. Os sinais clínicos da forma septicêmica são inespecíficos e de pouco auxílio no direcionamento do diagnóstico. A IHQ mostrou-se eficiente na detecção do agente principalmente no pulmão e especialmente nas situações em que não é possível a realização da cultura bacteriana.

TERMOS DE INDEXAÇ̃̃O: Salmonelose, bezerros, doenças de bovinos, Salmonella Dublin, septicemia, imuno-histoquímica, bovinos, bacterioses.

\section{INTRODUCTION}

Salmonellosis is a worldwide-distributed disease affecting several animal species (Radostits et al. 2007). It is a significant cause of economic loss in the cattle industry (Marques et al. 2013) due to reduced performance of affected animals, losses related to deaths, and costs involved in diagnostic methods, treatment and implementation of preventive and control measures (Radostits et al. 2007). There are two species: Salmonella enterica (comprising six subspecies) and Salmonella bongori. Most Salmonella of veterinary importance belong to the subspecies S. enterica subsp. enterica (Brenner et al. 2000). Within this subspecies, the Typhimurium and Dublin serotypes are the most frequent in cattle (Wray 1991). The former is responsible for causing enteric disease, especially in calves up to six months of age (Hughes et al. 1971). The second can affect cattle of all ages and is principally associated with severe septicemia (Baumler et al. 1998).

Reports describing the epidemiology, clinical and pathological aspect and laboratory diagnosis of septicemic salmonellosis in calves are frequent (Hall \& Jones 1977, Loeb et al. 2006, Marques et al. 2013, Costa et al. 2018). However, we were unable to find published documentation of the historical series of this disease addressing all of the previously mentioned aspects simultaneously.

Salmonellosis is considered one of the most important causes of diarrhea in calves up to 30 days old (El-Seedy et al. 2016). Accordingly, fecal samples are traditionally sent for bacteriological culture. However, septicemic animals may not present diarrhea (Wray 1991), which often makes diagnosis difficult. Recent studies show that although the pathogenesis of salmonellosis in calvevs is well characterized, the histological lesions of naturally acquired disease are still poorly detailed (Pecoraro et al. 2017). The present retrospective study describes the epidemiological, clinical, pathological and immunohistochemical aspects of septicemic salmonellosis in ten calves without enteric lesions and strongly positive immunostaining, especially in lung lesions.

\section{MATERIALS AND METHODS}

The protocols of 5,550 bovine necropsies were reviewed. These protocols were filed at the Anatomic Pathology Laboratory (LAP) of the "Faculdade de Medicina Veterinária e Zootecnia" (FAMEZ) of the "Universidade Federal de Mato Grosso do Sul" (UFMS). The necropsies studied were performed from January 1995 to July 2018 either by the faculty of LAP-FAMEZ or by practicing veterinarians. Materials from research projects and necropsied cattle from other states were not included in this survey. Only cases with calves aged 0 to 12 months with a confirmed or suggestive diagnosis of septicemic salmonellosis without enteric lesions were selected from the surveyed files.

Diagnostic criteria for previous selection of the cases were the presence of gross and microscopic findings considered to be characteristic of salmonellosis. These cases were confirmed by culture isolation of the bacterium and its identification in tissues by immunohistochemistry (IHC). In cases in which bacterial culture was not performed, diagnosis was confirmed solely by IHC.

Information on the year of occurrence, age and breed of calves, total number of exposed cattle, number of sick and dead animals, and results of complementary tests were also obtained from the protocols. The calves (Cases 1-10) were divided into dairy (Holstein-Friesian, Gir, Jersey, and Girolando) and beef (Angus, Brangus, and Senepol) cattle. Calves of unknown breeds were classified as mixed. The cases were organized chronologically by using Arabic numbers. An outbreak was considered when several cattle in the same farm were affected over a short period. The morbidity and lethality rates were calculated considering the number of cattle at risk (Thrusfield 2004), which was defined as the total cattle that remained in the same environment as the affected calves.

Liver, lung, and spleen sections (Cases 3-10) were also subjected to IHC with a polyclonal anti-Salmonella antibody, as previously described (Juffo et al. 2017). 


\section{RESULTS}

In the 23-year period of the study, samples from 5,550 bovine necropsies were analyzed, and 14 cases of salmonellosis were identified. Of these 14 cases, eleven were diagnosed with septicemic salmonellosis, ten of which had no enteric lesions. Eight (Cases 1-6, 8 and 9) of these ten cases were confirmed by isolating the bacterium in culture. Polymerase chain reaction (PCR) identified the agent as Salmonella Dublin in four cases (Cases 2, 3, 5 and 6). Spleen smears confirmed coinfection with Anaplasma sp. in three calves (Cases 1, 6 and 9) that also presented icterus. Diarrhea was reported in only three calves, but in these calves, there were no gross or microscopic changes consistent with diarrhea. Epidemiological data and information on the examinations performed on affected calves are presented in Table 1. Clinical signs are listed in Table 2. Necropsy findings refer to ten necropsied calves. There was pallor of the mucosae in five of the cases and icterus in three cases. Feces were adhered to the perineum in one case. In four cases, there was excess fluid in the thoracic and abdominal cavities, and fibrin could be observed covering the serosal surfaces of the body cavities in three cases. In nine of the cases, there was hepatomegaly, and the liver parenchyma had a yellow, orange, or tan hue (Fig.1A). In three cases, the gallbladder was distended by inspissated bile. Splenomegaly was observed in seven of the cases (Fig.1B). In half of the cases, the lungs were heavy, and impressions of the ribs in the pleural surface did not collapse when the thoracic cavity was opened (Fig.1C). At the cut surface, there was marked interstitial edema characterized by distension of the interlobular septa by gelatinous translucent exudate (Fig.1D). The results of the histopathological findings are summarized in Table 2 and illustrated in Figure 2A-D.

By using IHC, immunoreactivity was found in the liver ( $7 / 8$ cases), lung ( $7 / 8$ cases), and spleen (2/8 cases). The strongest marking was found in the lung (Fig.3). The morbidity and lethality rates varied from 2.5 to $85.71 \%$ and from 20 to $100 \%$, respectively.

Table 1. Epidemiological data and diagnostic tests performed to confirm the diagnosis of the cases of salmonellosis in calves without enteric lesions

\begin{tabular}{|c|c|c|c|c|c|c|c|c|c|}
\hline \multirow{2}{*}{$\begin{array}{c}\text { Outbreak } \\
\text { no. }\end{array}$} & \multirow{2}{*}{ Year } & \multirow{2}{*}{$\begin{array}{c}\text { Age } \\
\text { (months) }\end{array}$} & \multirow{2}{*}{ Breed } & \multirow{2}{*}{ At risk } & \multirow{2}{*}{ Sick } & \multirow{2}{*}{ Dead } & \multicolumn{3}{|c|}{ Tests } \\
\hline & & & & & & & Culture & $\mathrm{PCR}^{\mathrm{d}}$ & $\mathrm{IHC}^{\mathrm{f}}$ \\
\hline $1^{\mathrm{b}}$ & 2009 & 7 & Brangus & $\mathrm{NI}^{\mathrm{a}}$ & 10 & 2 & Positive & $\mathrm{NP}^{\mathrm{e}}$ & $\mathrm{NP}^{\mathrm{e}}$ \\
\hline $2^{c}$ & 2014 & $\mathrm{NI}^{\mathrm{a}}$ & Holstein-Friesian & $\mathrm{NI}^{\mathrm{a}}$ & 4 & 4 & Positive & S. dublin & $\mathrm{NP}^{\mathrm{e}}$ \\
\hline $3^{c}$ & 2014 & 3 & Senepol & $\mathrm{NI}^{\mathrm{a}}$ & 2 & 2 & Positive & S. dublin & Positive \\
\hline $4^{c}$ & 2015 & 1 & Senepol & $\mathrm{NI}^{\mathrm{a}}$ & 1 & 1 & Positive & NP & Positive \\
\hline $5^{c}$ & 2016 & 2 & Jersey & 80 & 20 & 20 & Positive & S. dublin & Positive \\
\hline $6^{c}$ & 2016 & 2 & Mixed & 122 & 3 & 3 & Positive & S. dublin & Positive \\
\hline $7^{c}$ & 2016 & 3 & Girolando & $\mathrm{NI}^{\mathrm{a}}$ & 1 & 1 & $\mathrm{NP}^{\mathrm{e}}$ & $\mathrm{NP}^{\mathrm{e}}$ & Positive \\
\hline $8^{c}$ & 2017 & 2 & Mixed & $\mathrm{NI}^{\mathrm{a}}$ & 2 & 2 & Positive & $\mathrm{NPe}$ & Positive \\
\hline $9^{c}$ & 2017 & 1 & Girolando & 7 & 6 & 2 & Positive & $\mathrm{NP}^{\mathrm{e}}$ & Positive \\
\hline $10^{\mathrm{b}}$ & 2018 & 2 & Girolando & $\mathrm{NI}^{\mathrm{a}}$ & 2 & 2 & $\mathrm{NP}^{\mathrm{e}}$ & $\mathrm{NP}^{\mathrm{e}}$ & Positive \\
\hline
\end{tabular}

$\overline{{ }^{\mathrm{a}} \text { Not informed, }{ }^{\mathrm{b}} \text { mailed-in samples, }}{ }^{\mathrm{c}}$ necropsied by the authors, ${ }^{\mathrm{d}}$ polymerase chain reaction, ${ }^{\mathrm{e}}$ not performed, ${ }^{\mathrm{f}}$ immunohistochemistry.

Table 2. Microscopic findings on cases of salmonellosis in calves (1995-2018)

\begin{tabular}{|c|c|c|c|}
\hline Organ & Microscopic lesion & Number of cases & Total (\%) \\
\hline \multirow[t]{4}{*}{ Liver } & Paratyphoid nodules (Fig.2A,B) & $10 / 10$ & 100 \\
\hline & Thrombosis & $4 / 10$ & 40 \\
\hline & Cholestasis & $4 / 10$ & 40 \\
\hline & Bacterial clusters & $3 / 10$ & 30 \\
\hline \multirow[t]{5}{*}{ Lung } & Interstitial pneumonia (Fig. 2C) & $9 / 10$ & 90 \\
\hline & Hyaline membrane (Fig.2C,D) & $6 / 10$ & 60 \\
\hline & Bacterial clusters & $4 / 10$ & 40 \\
\hline & Proliferation of type II pneumocyte & $2 / 10$ & 20 \\
\hline & Thrombosis & $1 / 10$ & 10 \\
\hline \multirow[t]{4}{*}{ Spleen } & Follicular necrosis & $3 / 10$ & 30 \\
\hline & Paratyphoid nodules & $3 / 10$ & 30 \\
\hline & Thrombosis & $2 / 10$ & 20 \\
\hline & Bacterial clusters & $1 / 10$ & 10 \\
\hline \multirow[t]{2}{*}{ Rete mirabile } & Thrombosis & $1 / 10$ & 10 \\
\hline & Bacterial clusters & $1 / 10$ & 10 \\
\hline Leptomeninges & Mononuclear/neutrophilic infiltrate & $3 / 10$ & 30 \\
\hline \multirow[t]{2}{*}{ Brain } & Neutrophilic perivascular cuffings & $1 / 10$ & 10 \\
\hline & Thrombosis & $1 / 10$ & 10 \\
\hline
\end{tabular}



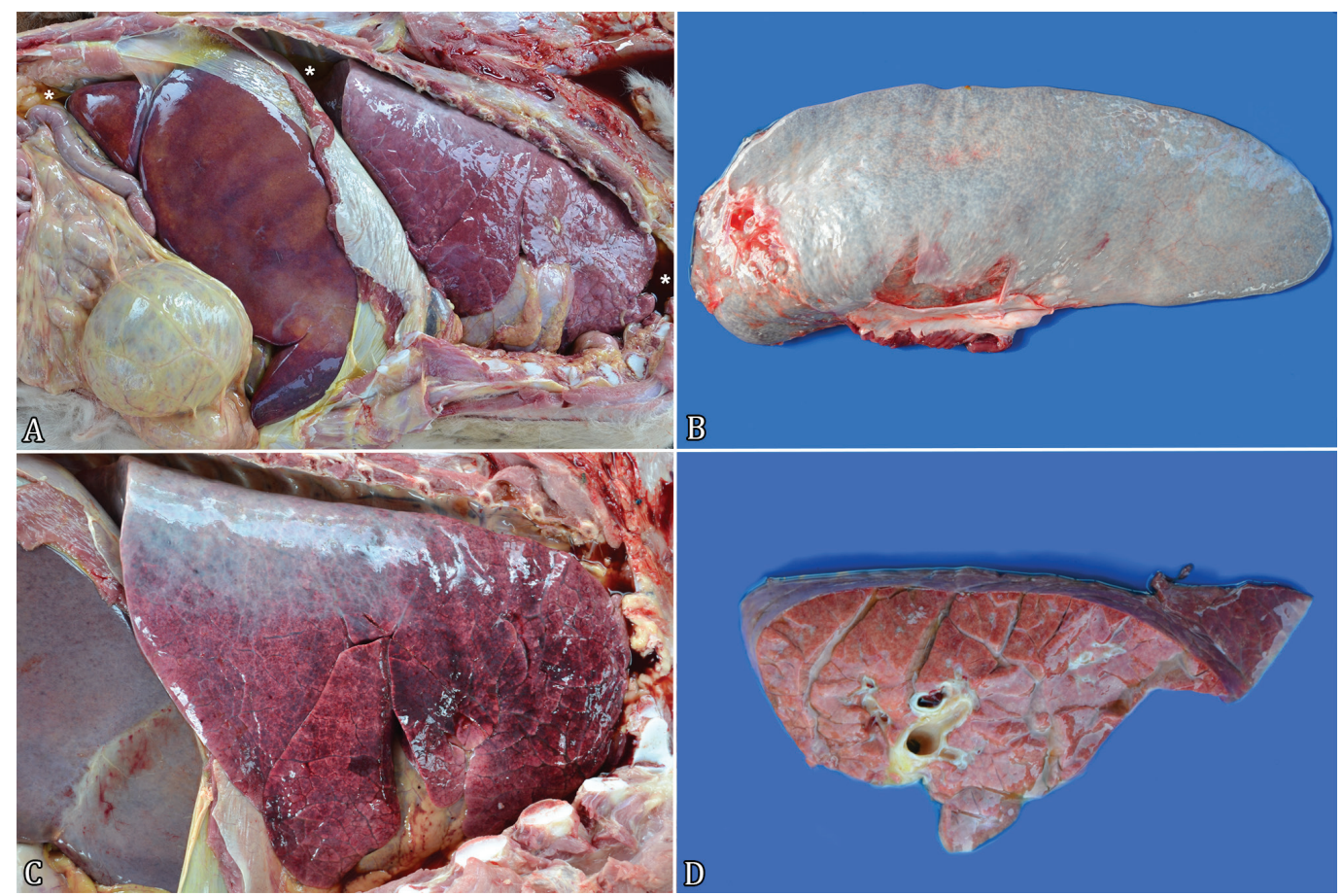

Fig.1 Gross findings in calves with septicemic salmonellosis. (A) There is an excess of clear yellow fluid in the thoracic (hydrothorax) and abdominal (ascites) cavities (asterisks). The liver is enlarged and displays the impression of the ribs on its capsular surface. Compressed liver areas have an orange hue. The lung is poorly collapsed and has a smooth, bright and reddened surface, which is marked by impression of the ribs. (B) Enlargement of the spleen is evident from the rounded borders and slight capsular tension. (C) Lung not collapsed. The pleural surface is smooth, reddened and bright. (D) Lung, cut surface, marked distension of interlobular septa by translucent gelatinous exudate (edema).

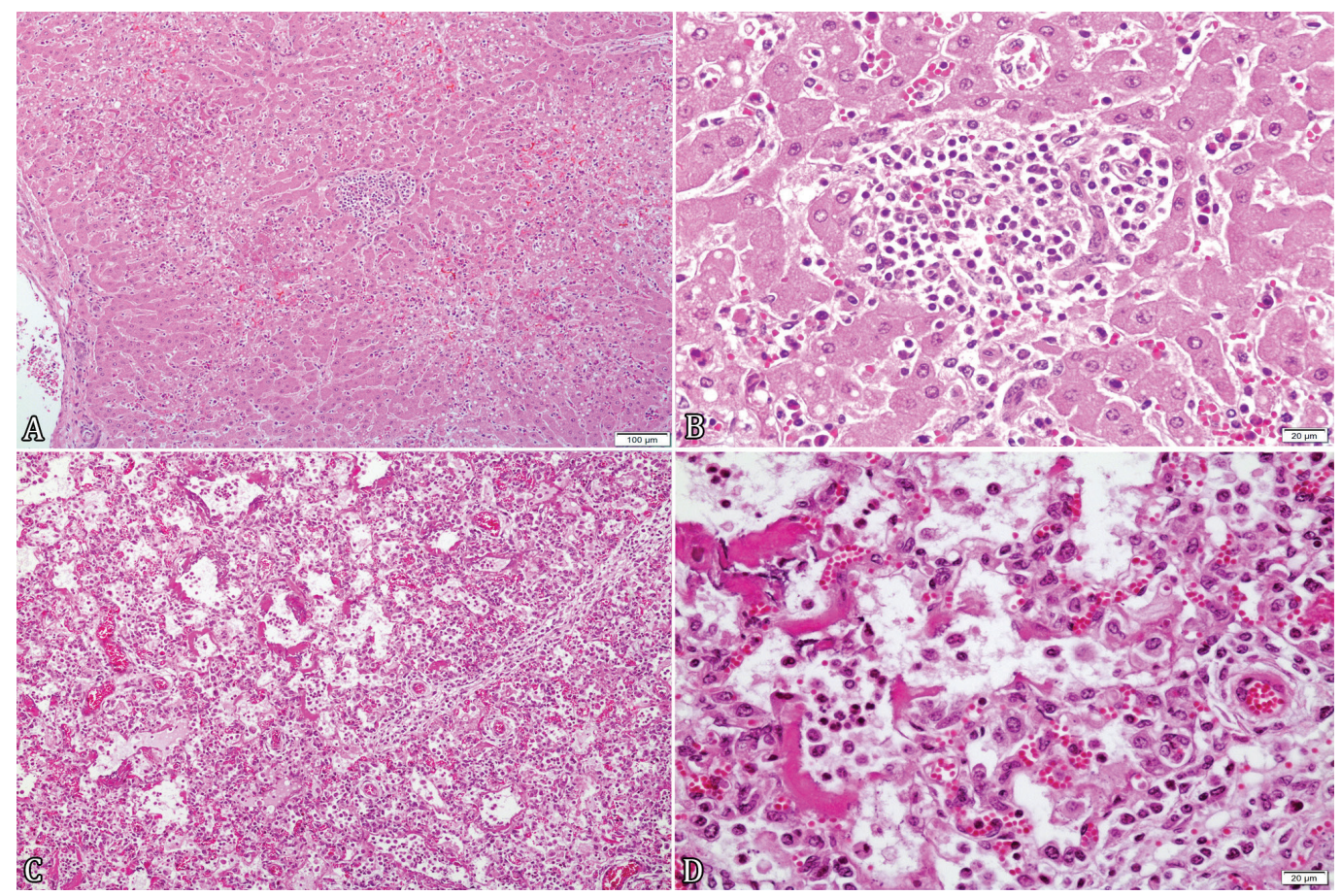

Fig.2 Histological lesions in calves with septicemic salmonellosis. (A) Paratyphoid nodules. Multiple granulomas are distributed throughout the liver parenchyma. HE, obj.20x. (B) One granulomatous nodule was composed of mononuclear cells (macrophages and lymphocytes). Red blood cell precursors can be seen with sinusoids. HE, obj.40x. (C) Lung. Bird's eye view of the pulmonary lesion. Interstitial pneumonia. The alveolar septa are thickened by a mononuclear infiltrate, and the alveolar line is covered by a hyaline membrane. Pink transudate (edema) is observed in the alveoli lumen, and the interlobular septa are distended and infiltrated by inflammatory mononuclear cells. HE, obj.20x. (D) Lung. A higher magnification of Figure 2C shows the proliferation of type II pneumocytes. Note also the thickened alveolar septa and hyaline membrane. HE, obj.40x. 


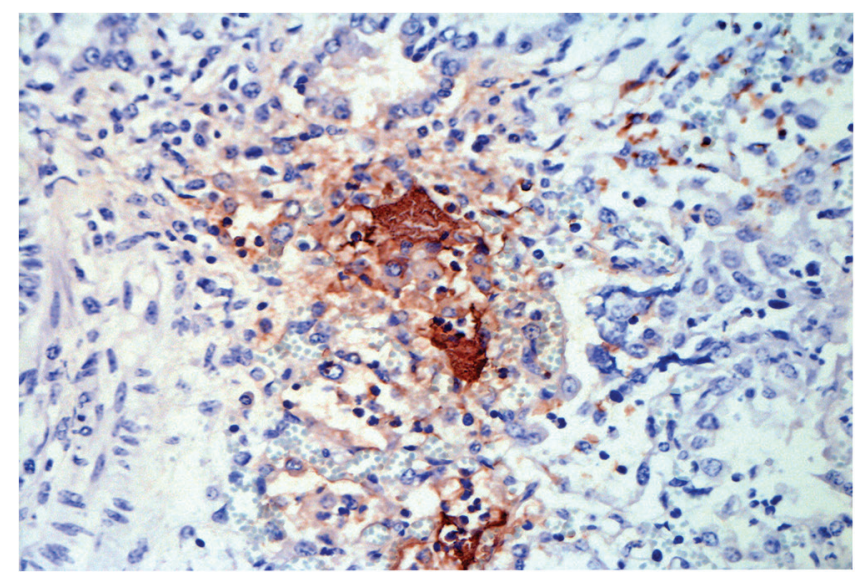

Fig.3. Polyclonal anti-Salmonella antibody. Lung. The strongest marking was found in the lung. IHC, obj.40x.

\section{DISCUSSION}

The number of cases of septicemic salmonellosis was low $(0.2 \%)$ compared to the total number of bovine samples analyzed during the studied period. The prevalence of the disease was also low in surveys conducted by other diagnostic laboratories in Brazil, ranging from 0.6\% (Lucena et al. 2010) to $0.9 \%$ (Assis-Brasil et al. 2013).

Although bovine salmonellosis is a frequent disease in other countries (Hughes et al. 1971, Carrique-Mas et al. 2010), surveys describing the clinical, epidemiological and pathological aspects of salmonellosis are not universal. Although salmonellosis can affect cattle of all ages (Hughes et al. 1971), only calves between seven and 40 days of age were affected in the present survey. Cattle from one to three months of age were the most frequently affected, accounting for $80 \%$ of all cases. Similar data were observed in cattle from other regions of Brazil (Marques et al. 2013), Uruguay (Costa et al. 2018) and the United States (Pecoraro et al. 2017).

Documentation of salmonellosis is more common in dairy cattle (Radostits et al. 2007); however, in the present study, it was observed in both dairy and beef calves. Regardless of cattle breed, several risk factors may contribute to the manifestation of this disease: 1) keeping calves of different ages in the same environment, resulting in exposure of the very young that still do not have enough colostral immunity; 2) providing drinking water that may contain feces contaminated with Salmonella spp.; 3) moving calf carriers, which reactivates the bacteria and releases them into the environment after a period of stress; 4) keeping calves close to rodents and wild birds, which are common sources of the bacteria (Wray 1991, Vaessen et al. 1998, Warnick et al. 2001, Fenwick \& Collett 2004, Radostits et al. 2007, Blanchard 2012).

Clinical signs included diarrhea, mucosa pallor, apathy, hyperthermia, and respiratory distress. Two calves were found dead, and no previous clinical signs were observed. Considering that salmonellosis frequently causes diarrhea (Radostits et al. 2007) and interstitial pneumonia (Pecoraro et al. 2017), intestinal and respiratory clinical signs may be considered essential in the differentials list for this disease. As some of these clinical signs may also occur in several other diseases, their diagnostic value is less significant than the others. The three calves with jaundice in this study had concomitant infection with Anaplasma sp. Thus, jaundice cannot be attributed to salmonellosis.

Hepatosplenomegaly; yellowish, orange or brownish liver; pallor of mucous membranes, noncollapsed red and wet lungs; serosal body cavities containing serous fluid or fibrin-covered serous membranes; and gallbladder containing inspissated bile were common gross findings observed in $20-90 \%$ of the affected calves. As reported by others (Marques et al. 2013, Pecoraro et al. 2017), paratyphoid nodules (found in all calves) and interstitial pneumonia were the most common histopathological findings. Although fibrinous cholecystitis is considered a pathognomonic finding of salmonellosis (Mohler et al. 2009), it was not found in the calves of this study. Thus, the mere absence of this characteristic lesion cannot be the grounds for ruling out salmonellosis, and systematic sampling of tissues for complementary tests is advised in cases presenting other characteristic signs and lesions.

PCR detected Salmonella Dublin as the cause in four calves. Although Salmonella Typhimurium may also cause septicemia (Baumler et al. 1998, La Ragione et al. 2013), Salmonella Dublin is the main serotype associated with this form of clinical presentation (Wray 1991, Santos et al. 2001). This form of salmonellosis was described in an outbreak in Northern Brazil that involved the serovar Dublin (Marques et al. 2013).

Surveys describing the main types of manifestation of salmonellosis involving periods of several years have not been performed in Brazil, while in Europe (Carrique-Mas et al. 2010), the Dublin serovar has been reported to have a high prevalence and cause clinical signs suggestive of septicemia. However, in that account, the diagnosis was based mainly on the database of the UK diagnostic service, no details of necropsy or histopathological findings were reported, and diarrhea was noted as the most common manifestation (Carrique-Mas et al. 2010).

In the ten cases of septicemic salmonellosis in this study, diarrhea was observed only in three cases, which is in agreement with previous studies (Hughes et al. 1971, Wray 1991, Holschbach \& Peek 2018) and demonstrates that diarrhea is not always associated with salmonellosis. This may be a reason for the underreporting of the disease because, in the absence of diarrhea, many veterinarians do not seek further testing for bacterial isolation from fresh or refrigerated samples of feces, liver, and bile nor do they order histopathological examination of organs such as intestine, liver, gallbladder, and lung.

It is noteworthy that most of the described clinical and pathological data described in this study were observed in cases where the LAP-FAMEZ staff performed the necropsy. Most of the mailed-in cases were not correctly sampled and were accompanied by limited clinical information. This, of course, compromises the diagnosis, as incorrect sampling may not provide fragments from all required organs for microscopic evaluation and no samples for bacterial isolation. When dead calves are submitted, usually advanced autolysis and putrefaction hinder the possibility of bacterial isolation (Strafuss 1988). This nonproper submission of material for diagnosis is not restricted to cases of salmonellosis and is frequently observed in many veterinary diagnostic laboratories (Lucena et al. 2010, Souza et al. 2015). 
The use of IHC for the diagnosis of salmonellosis is described in sheep (Dagleish et al. 2010), horses (Juffo et al. 2017), swine (Watanabe et al. 2011), turkeys (Beyaz et al. 2010) and cattle (Pecoraro et al. 2017, Costa et al. 2018). In all analyzed materials in the present study, there was positive immunoreactivity in the liver and lung. In two calves, the spleen also tested positive under IHC. In contrast to a case described previously (Pecoraro et al. 2017), in which the liver was the principal organ of detection of the bacterium, the lung was the organ with the strongest positive marking by IHC in this study. Accordingly, lung fragments should always be included in the list of organs sent for IHC analysis in suspected cases of salmonellosis.

Similar to previous studies (Beyaz et al. 2010, Juffo et al. 2017), in two cases in this study, confirmation of salmonellosis was only possible with IHC because sampling-related problems precluded bacterial culture. In such cases, IHC becomes an essential tool for verifying the diagnosis of bovine salmonellosis. IHC should be used even in cases of negative bacterial culture results and for which epidemiological, clinical and pathological data suggest salmonellosis.

\section{CONCLUSIONS}

Septicemia was the leading cause of death by salmonellosis in calves.

In most cases, diarrhea was not a clinical sign.

The clinical signs were mostly nonspecific and of little assistance in directing the diagnosis.

IHC proved to be efficient in detecting the agent, which was detected mainly in the lung, and it was especially valuable when it was not possible to perform bacterial culture.

In cases of death of calves without the manifestation of diarrhea, Salmonella should be included in the list of differential diagnoses, thus requiring samples of liver, spleen, lung, and intestine for complementary laboratory diagnostic tests.

Acknowledgements.- One of the authors (RAAL) has a research fellowship from the Brazilian "Conselho Nacional de Desenvolvimento Científico e Tecnológico" (CNPq). This study was partially funded by the "Coordenação de Aperfeiçoamento de Pessoal de Nível Superior" (CAPES), Brasil, Finance Code 001, and by "Fundação de Apoio ao Desenvolvimento do Ensino, Ciência e Tecnologia do Estado de Mato Grosso do Sul" (Fundect).

Conflict of interest statement.- The authors have no competing interests.

\section{REFERENCES}

Assis-Brasil N.D., Marcolongo-Pereira C., Hinnah F.L., Ladeira S.R.L., Sallis E.S.V., Grecco F.B. \& Schild A.L. 2013. Enfermidades diagnosticadas em bezerros na região sul do Rio Grande do Sul. Pesq. Vet. Bras. 33(4):423-430. <http://dx.doi.org/10.1590/S0100-736X2013000400002>

Bäumler A.J., Tsolis R.M., Ficht T.A. \& Adams L.G. 1998. Evolution of host adaptation in Salmonella enterica. Infect. Immun. 66(10):4579-4587. <PMid:9746553>

Beyaz L., Atasever A., Aydin F., Gümüşsoy K.S. \& Abay S. 2010. Pathological and clinical findings and tissue distribution of Salmonella gallinarum infection in Turkey poults. Turk. J. Vet. Anim. Sci. 34(2):101-110.

Blanchard P.C. 2012. Diagnostics of dairy and beef cattle diarrhea. Vet. Clin. N. Am., Food Anim. Pract. 28(3):443-464. <http://dx.doi.org/10.1016/j. cvfa.2012.07.002><PMid:23101670>
Brenner F.W., Villar R.G., Angulo F.J., Tauxe R. \& Swaminathan B. 2000. Salmonella nomenclature. J. Clin. Microbiol. 38(7):2465-2467. <PMid:10878026>

Carrique-Mas J.J., Willmington J.A., Papadopoulou C., Watson E.N. \& Davies R.H. 2010. Salmonella infection in cattle in Great Britain, 2003 to 2008. Vet. Rec. 167(15):560-565. <http://dx.doi.org/10.1136/vr.c4943> <PMid:21257417>

Costa R.A., Casaux M.L., Caffarena R.D., Macias-Rioseco M., Schild C.O., Fraga M., Riet-Correa F. \& Giannitti F. 2018. Urocystitis and ureteritis in holstein calves with septicaemia caused by Salmonella enterica serotype Dublin. J. Comp. Path. 164:32-36. <http://dx.doi.org/10.1016/j.jcpa.2018.08.005> $<$ PMid:30360910>

Dagleish M.P., Benavides J. \& Chianini F. 2010. Immunohistochemical diagnosis of infectious diseases of sheep. Small Rum. Res. 92(1):19-35. <http:// dx.doi.org/10.1016/j.smallrumres.2010.04.003>

El-Seedy F.R., Abed A.H., Yanni H.A. \& Abd El-Rahman S.A.A. 2016. Prevalence of Salmonella and E. coli in neonatal diarrheic calves. Beni-Seuf Univ. J. Appl. Sci. 5(1):45-51.

Fenwick S.G. \& Collett M.G. 2004. Bovine salmonellosis, p.1582-1594. In: Coetzer J.A.W. \& Tustin R.C. (Eds), Infectious Diseases of Livestock. Oxford University Press, Southern Africa.

Hall G.A. \& Jones P.W. 1977. A study of the pathogenesis of experimental Salmonella Dublin abortion in cattle. J. Comp. Pathol. 87(1):53-65. <http:// dx.doi.org/10.1016/0021-9975(77)90079-2><PMid:557060>

Holschbach C.L. \& Peek S.F. 2018. Salmonella in dairy cattle. Vet. Clin. N. Am., Food Anim. Pract. 34(1):133-154. <http://dx.doi.org/10.1016/j. cvfa.2017.10.005><PMid:29224803>

Hughes L.E., Gibson E.A., Roberts H.E., Davies E.T., Davies G. \& Sojka W.J. 1971. Bovine salmonellosis in England and Wales. Brit. Vet. J. 127(5):225-238. <http://dx.doi.org/10.1016/S0007-1935(17)37588-7><PMid:4931663>

Juffo G.D., Bassuino D.M., Gomes D.C., Wurster F., Pissetti C., Pavarini S.P. \& Driemeier D. 2017. Equine salmonellosis in southern Brazil. Trop. Anim. Health Prod. 49(3):475-482. <http://dx.doi.org/10.1007/s11250-0161216-1> <PMid:28013440>

La Ragione R., Metcalfe H.J., Villarreal-Ramos B. \& Werling D. 2013. Salmonella infections in cattle, p.233-262. In: Barrow P.A. \& Methner U. (Eds), Salmonella in Domestic Animals. CABI, Oxfordshire. <http://dx.doi.org/10.1079/97 81845939021.0233>.

Loeb E., Toussaint M.J., Rutten V.P. \& Koeman J.P. 2006. Dry gangrene of the extremities in calves associated with Salmonella Dublin infection; a possible immune-mediated reaction. J. Comp. Pathol. 134(4):366-369. <http:// dx.doi.org/10.1016/j.jcpa.2006.01.005><PMid:16707135>

Lucena R.B., Pierezan F., Kommers G.D., Irigoyen L.F., Fighera R.A. \& Barros C.S.L. 2010. Doenças de bovinos no Sul do Brasil: 6.706 casos. Pesq. Vet. Bras. 30(5):428-434. <http://dx.doi.org/10.1590/S0100736X2010000500010>

Marques A.L.A., Simões S.V.D., Garino Junior F., Maia L.A., Silva T.R.D., RietCorrea B., Lima E.F. \& Riet-Correa F. 2013. Surto de salmonelose pelo sorovar Dublin em bezerros no Maranhão. Pesq. Vet. Bras. 33(8):983-988. <http://dx.doi.org/10.1590/S0100-736X2013000800006>

Mohler V.L., Izzo M.M. \& House J.K. 2009. Salmonella in calves. Vet. Clin. N. Am. Food Anim. Pract. 25(1):37-54. <http://dx.doi.org/10.1016/j. cvfa.2008.10.009>

Pecoraro H.L., Thompson B. \& Duhamel G.E. 2017. Histopathology case definition of naturally acquired Salmonella enterica serovar Dublin infection in young Holstein cattle in the northeastern United States. J. Vet. Diagn. Invest. 29(6):860-864. <http://dx.doi.org/10.1177/1040638717712757> $<$ PMid:28599615>

Radostits O.M., Gay C.C., Hinchcliff K.W. \& Constable P.D. 2007. Diseases associated with Salmonella species, p.896-920. In: Constable P.D., 
Hinchcliff K.W., Done S.H. \& Grünberg W. (Eds), Veterinary Medicine: a textbook of the diseases of cattle, sheep, goats, pigs and horses. W.B. Saunders, Philadelphia.

Santos R.L., Zhang S., Tsolis R.M., Kingsley R.A., Adams L.G. \& Baumler A.J. 2001. Animal models of Salmonella infections: enteritis versus typhoid fever. Microbes Infect. 3(14/15):1335-1344.<http://dx.doi.org/10.1016/ S1286-4579(01)01495-2><PMid:11755423>

Souza R.I.C., Santos A.C., Ribas N.L.K.S., Colodel E.M., Leal P.V., Pupin R.C., Carvalho N.M. \& Lemos R.A.A. 2015. Doenças tóxicas de bovinos em Mato Grosso do Sul. Semina, Ciênc. Agrárias 36(3):1355-1368. <http://dx.doi. org/10.5433/1679-0359.2015v36n3p1355>

Strafuss A.C. 1988. Specimen collection and submission, p.71-86. In: Thomas C.C. (Eds), Necropsy: simplified procedures and basic diagnostic methods for praticing veterinarians. Thomas Books, Springfield.
Thrusfield M.V. 2004. Descrevendo ocorrência de doenças, p.47-76. In: Thomas C.C. (Eds), Epidemiologia Veterinária. Roca, São Paulo.

Vaessen M.A., Veling J., Frankena K., Graat E.A. \& Klunder T. 1998. Risk factors for Salmonella Dublin infection on dairy farms. Vet. Q. 20(3):97-99. <http:// dx.doi.org/10.1080/01652176.1998.9694848> <PMid:9684297>

Warnick L.D., Crofton L.M., Pelzer K.D. \& Hawkins M.J. 2001. Risk factors for clinical salmonellosis in Virginia, USA cattle herds. Prev. Vet. Med. 49(3/4):259-275. <http://dx.doi.org/10.1016/S0167-5877(01)00172-6><PMid:11311958>

Watanabe T.T.N., Zlotowski P., Oliveira L.G.S., Rolim V.M., Gomes M.J.P., Snel G. \& Driemeier D. 2011. Rectal stenosis in pigs associated with Salmonella typhimurium and porcine circovirus type 2 (PCV2) infection. Pesq. Vet. Bras. 31(6):511-515. <http://dx.doi.org/10.1590/S0100736X2011000600009>

Wray C. 1991. Salmonellosis in cattle. In Practice 13(1):13-15. <http:// dx.doi.org/10.1136/inpract.13.1.13> 